\title{
Evolution of minesoils at a coal waste pile: A case study from Rosice-Oslavany (Czech Republic)
}

\author{
Martin IVANOV*, Jiři FAIMON, Petr JARMARA \& Lubomír PEŠÁK \\ ${ }^{1}$ Department of Geological Sciences, Faculty of Science, Masaryk University, Kotlářská 2, 61137 Brno, Czech Republic
}

Received March 2009; accepted June 2009

Available online June 2009

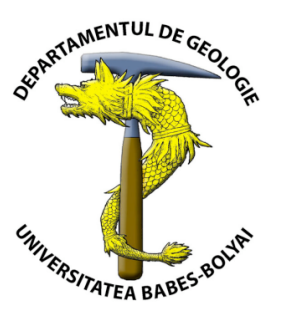

\begin{abstract}
Mine soil development at abandoned coal waste pile (Kukla-Václav Nosek mine, Oslavany) represents a possibility to study initial stages of pedogenetic process. Seven soil profiles were uncovered by digging pits at the base and on the slopes and top of the waste pile. Several conclusions concerning soil development at waste pile are possible on the basis of soil profiles description and basic chemistry: 1. Intensive humification was the main pedogenetic process in the initial stages of mine soil evolution at the Kukla waste pile. There is no translocation of clay minerals even in the soil profiles evolving for about 60 years; 2 . The youngest soil situated on the top of the waste pile has the most stable granular aggregates. The stability of aggregates corresponds to the increased representation of the total organic matter; 3 . Humus quality of the present topsoils in the Kukla waste pile is substantially influenced by the biological recultivation.
\end{abstract}

Key words: coal waste pile, soil development, humification, Czech Republic.

\section{INTRODUCTION}

The mine soil development at abandoned coal spoils represents a relatively rare possibility to study initial stages of pedogenetic process within industrial areas of Central Europe. There is no uniformity in mine soil classification (Sencindiver, 1977; Sencindiver et al., 1978; Sencindiver and Ammons, 2000). The Committee on Anthropogenic Soils (ICOMANTH) considers mine soils to be anthropogenic because of conspicuous alteration by human activity (cf. Sencindiver and Ammons, 2000). Although as many as thirty mine soil series established on lands mined for coal have been grouped into a new suborder of Spolents (within Entisols) (Ammons and Sencindiver, 1990; Sencindiver et al., 1978; Thurman and Sencindiver, 1986; Thurman et al., 1985), the new World Reference Base for Soil Resources 2006 (IUSS Working Group WRB, 2006) established a new soil group, i.e., Technosols that also encompasses the soils developed on mine spoils.

Several factors are of particular significance for progressive mine soil formation (e.g., Thomas and Jansen, 1985; Bradshaw, 1987; Benfeldt et al., 2001). These include: (1) petrology of parental (spoil) material, (2) climate conditions, (3) vegetation cover/SOM (soils organic material) content, and (4) time from the last accumulation of the spoil material. The basic condition for natural soil formation is a combination of weathering process and organic material accumulation (Gobat et al., 2004). Rapid weathering of parent material never leads to mature soils. A solum thickness is a function of soil increasing age. Ahorizon is the first distinctly developed horizon that typically shows increased SOM accumulation and has a poor structure (Němeček et al., 1990; Gobat et al., 2004).

Minesoil evolution is much more rapid in comparison to natural soils (Thomas and Jansen, 1985). A-horizon (up to 6 $\mathrm{cm}$ ) can develop even on two-years-old spoils if they were reclaimed (Thomas et al., 2000). Moreover, the thickness of A-horizon seems to be strongly dependent on the nature of the parent material (e.g. texture, clay content). In particular, rapid soil formation occurs on reclaimed mine spoils (Daniels et al., 2004; Haering et al., 2004).

\section{METHODS}

The soil evolution study focused on the waste pile of the closed Kukla-Václav Nosek coal mine situated in the NW part of the Oslavany town, Czech Republic (Fig. 1A, B). The mining activities ceased in 1973, but the waste pile was recultivated in 1992 when its two waste rock cones were lowered into a depression separating both cones. Subsequent biological reclamation was based on revegetation using hydroseeding and tree planting. The pile burned from the late $19^{\text {th }}$ century until the $1990 \mathrm{~s}$ and has acquired a zoned nature recently investigated by Dokoupilová et al. (2007) who reported (1) bituminous coal to anthracite, micas and goethite (i.e. primary minerals) in the black zone; (2) hematite, spinels and corundum in the red material produced by pyrometamorphism; and (3) hydrated Mg-sulphates on the slopes of the waste pile.

Seven soil profiles were uncovered by digging small pits (P1-P7) at the base and on the slopes and top of the waste pile (Fig. 1B). One pit was situated on the top of the flat recultivated waste pile. Basic soil characteristics/attributes were investigated including soil thickness, texture, structure, color, and basic chemistry. The anhydromorphic humic Ahorizon was thoroughly studied.

The period from the last waste rock accumulation was estimated (P1-P5 30 years; P6 12 years; P7 60 years) (Plchová, 2002; pers. comm.). 


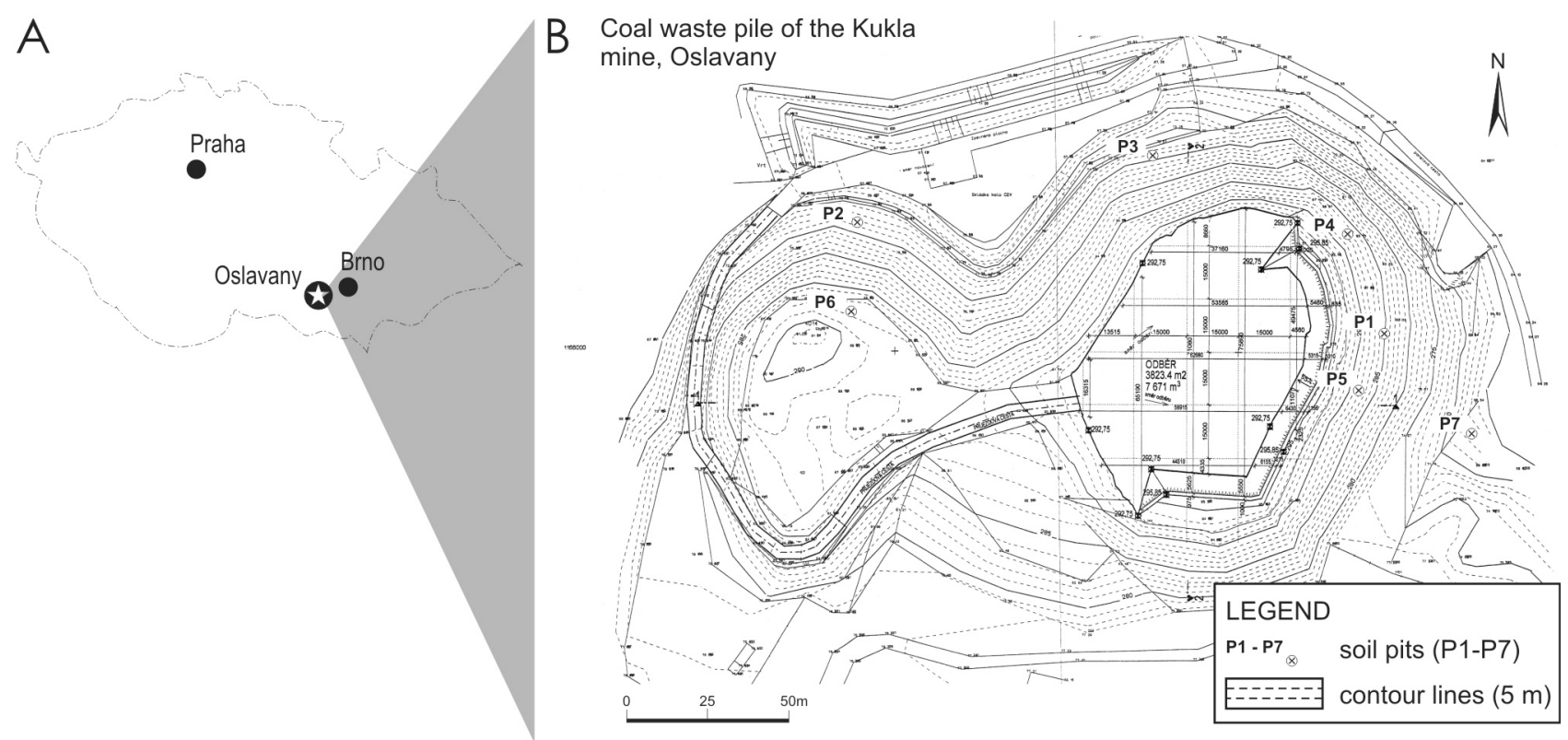

Fig. 1 A. Location of the Oslavany site; B. Location of soil profiles on the coal waste pile (modified from: DIAMO state enterprise, Dolni Rožinka).

Soil texture (NRCS USDA classification) was determined by sieving (RETSCH AS200 Basic with normalized sieves). Soil grains $<0.063 \mathrm{~mm}$ were analyzed by LOGITECH laser gravelometer. Soil color was estimated by X-Rite ColorMaster spectrometer and subsequently converted to the Munsell Color System by the Munsell Conversion Software (version 8.0.3).

The soil samples were analyzed for: soil alkalinity/acidity $\left(\mathrm{pH} / \mathrm{H}_{2} \mathrm{O} ; \quad \mathrm{pH} / \mathrm{KCl}\right)$ using saturated suspension and $\mathrm{pH}-\mathrm{meter}$; total organic carbon TOC (\%) using dichromate reduction of organic carbon and subsequent spectrophotometric measurement (WalkleyBlack Method), total N (\%) by the Total Kjeldahl Nitrogen (TKN), total organic matter T-OM (\%), total humine acids HA (\%), and fulvic acids FA (\%) by fractionation in $\mathrm{Na}_{2} \mathrm{H}_{2} \mathrm{P}_{2} \mathrm{O}_{7}$. All chemical analyses were performed at the Laborator̆ Morava, s.r.o.

Soil $\mathrm{CO}_{2}$ production was used as an indicator for the organic matter degradation extent. $\mathrm{CO}_{2}$-concentrations, temperature, and humidity were monitored in February and March 2008.

Fifteen probe holes were drilled out into soil horizon by steel bar (up to $70 \mathrm{~cm}$ in depth, $\sim 5 \mathrm{~cm}$ in diameter). The wall of each probe hole was reinforced with a cylinder of polyethylene and locked with a plastic cover. $\mathrm{CO}_{2}$-concentrations were measured by a handheld device (2-channel IR-detector FT A600-CO2H linked with ALMEMO 2290-4 V5, Ahlborn, Germany; measuring range: 0 to 10,000 ppmv; accuracy: (1) \pm 50 ppmv +2 vol. $\%$ of measured value in the range of 0 to $5000 \mathrm{ppmv}$, and $\pm 100 \mathrm{ppmv}+3 \mathrm{vol} \%$ of measured value in the range of 5,000 to $10,000 \mathrm{ppmv}$; resolution: 1 ppmv or 0.0001 vol.\%). Relative humidity (RH) and temperature of soil were monitored by digital hydro/thermometer GFTH 200, Greisinger electronic $\mathrm{GmbH}$, Germany (resolution: $0.1 \% \mathrm{RH}$ and $0.1^{\circ} \mathrm{C}$; measuring range: temperature: -25 to $+70^{\circ} \mathrm{C}$; $\mathrm{RH}: 0$ to $100 \%$; temperature accuracy: $\pm 0.5 \%$ of measured value $\pm 0.1^{\circ} \mathrm{C}$; humidity accuracy: $\pm 1.5 \%$ linearity, $\pm 1.5 \%$ hysteresis for $11-90 \%$ range).

\section{MINE SOIL PROFILES}

The pits $\mathrm{P} 1$ to $\mathrm{P} 7$ show simple profile including topsoil humic organomineral A-horizon and C-horizon, respectively. In all profiles, C-horizon was subdivided into two or more clearly distinct horizons $(\mathrm{C} 1, \mathrm{C} 2, \mathrm{C} 3)$. An intermediate AC-horizon ( $12 \mathrm{~cm}$ in thickness) was only observed in profile P7. This soil profile (the longest interval of development; \pm 60 years) is situated at the naturally developed eastern margin of the flat base of the waste pile. Thickness of the topsoil A-horizon is variable. It ranges from 2.7 to $13 \mathrm{~cm}$. The minimum thickness of the A-horizon occurred at $\mathrm{P} 3$ profile that was situated on a steep slope $\left(43^{\circ}\right)$. Thickness of the subsurface horizons is a result of accumulation of the waste rocks with no connection to the pedogenetic process.

Soil texture. The soil texture (NRCS USDA) corresponds to sandy-loamy soil. Horizons with loamy sand and silty loam occur only exceptionally. The soil skeleton represented by Permo-Carboniferous deposits consists of weathered sandstone, siltstone, and claystone with small coal pieces (rare occurrences up to $5 \%$ vol.). Humic Ahorizon has low skeleton volume (about $20 \%$ ), skeleton admixture occurs only in P4 (10\%). Rock fragments are usually weathered. Disintegration depends on the waste pile burning. For example, C-horizon of the P4 pit situated on the northern slope of the waste pile that contains $80 \%$ of rock fragments $(5-20 \mathrm{~cm})$ are extremely firm as a result of waste pile burning.

Color. The color variability of subsurface horizons is a result of successive material accumulation and subsequent long-lasting pile burning. The colorimetrical analysis in visible reflectance spectra indicates the presence of the $\mathrm{Fe}^{3+}$ bound in hematite $\left(\mathrm{Fe}_{2} \mathrm{O}_{3}\right)$, presence of which is a result of intensive oxidation process at waste pile burning (Dokoupilová et al., 2007). Although some horizons are intensively red colored, e.g. P2-C2 $(5.9 \mathrm{YR} / 6 / 2.9)$, the hematite content estimated from the fraction $<2 \mathrm{~mm}$ is very low in the Kukla waste pile ( $\sim 0.03 \%)$. This is not surprising because a considerable influence of low hematite doses on 
the intensive red coloring was confirmed by some experimental studies (Deaton and Balsam, 1991).

Soil chemistry. No trends were found in soil alkalinity/acidity $\left(\mathrm{pH} / \mathrm{H}_{2} \mathrm{O} ; \mathrm{pH} / \mathrm{KCl}\right)(1)$ with depth of any single profile or (2) between the profiles of different ages. This finding agrees with other previous researches (e.g. Thomas and Jansen, 1985). Topsoil humic horizons (Fig. 2A) show neutral to slightly acid reaction; whereas Ahorizon of the $\mathrm{P} 2$ pit shows more acid reaction $\left(\mathrm{pH} / \mathrm{H}_{2} \mathrm{O}=\right.$ 4.39). There is no correlation $\left(\mathrm{R}^{2}=0.06\right)$ between the total organic matter T-OM and the total organic carbon (TOC) (Fig. 2B), which indicates increasing admixture of coal ash in the horizons where T-OM/TOC is very low. This observation supports the assumption that very inclined slopes could be considered an important agent of the relative coal carbon content with the highest values just within the soils developing on the steepest slopes (P3-A: $\mathrm{T}-\mathrm{OM} / \mathrm{TOC}=0.04$; inclination $=43 \%)$. HA/FA ratio $($ Fig. 2A) indicates that humus of all studied mine soils shows good quality (HA/FA $>1$ ranging from 1.08 in P3-A up to 6.34 in $\mathrm{P} 4-\mathrm{C} 2)$. Extremely high $\mathrm{HA} / \mathrm{FA}$ ratios in some subsurface horizons $(\mathrm{P} 4-\mathrm{C} 2$ : $\mathrm{HA} / \mathrm{FA}=6.34$; $\mathrm{T}-\mathrm{OM}=2.57$ ) are most probably due to rapid vertical migration of the soil solution from the humic A-horizon and subsequent storage above less permeable layer. There is no trend between A-horizon thickness and humus quality (HA/FA).

However (Fig. 2C), humus of generally better quality occurs in topsoil horizons situated close to the upper, recultivated part of the waste pile $(\mathrm{HA} / \mathrm{FA}=1.53-2.00)$ in contrast to topsoil horizon of soils with longer period of soil evolution at the base of the pile $(\mathrm{HA} / \mathrm{FA}=1.33$ $1.39)$.
A
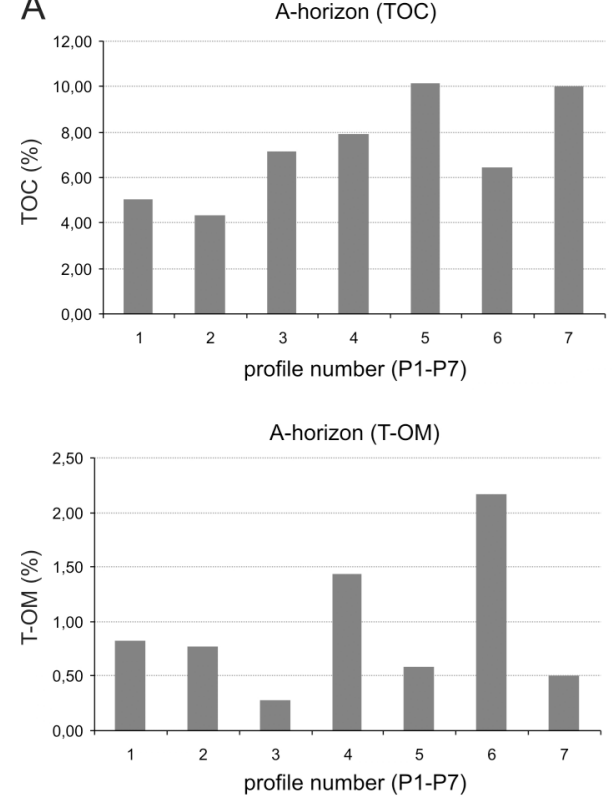

A-horizon (HA/FA)

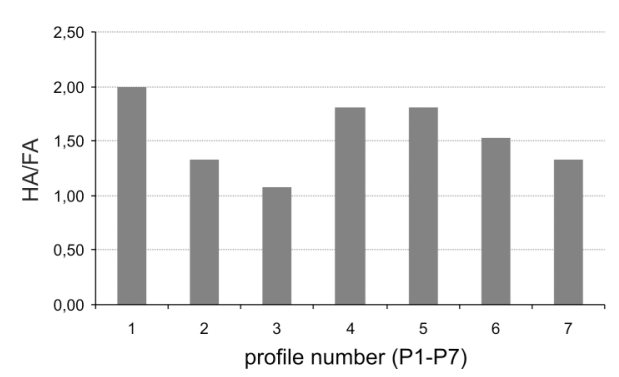

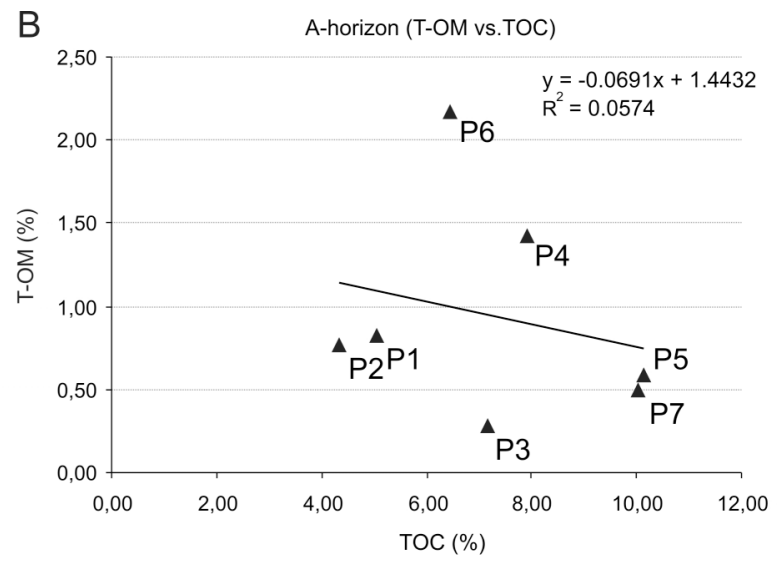

C

Record for 9 cases; Ward method; Euclid. distances

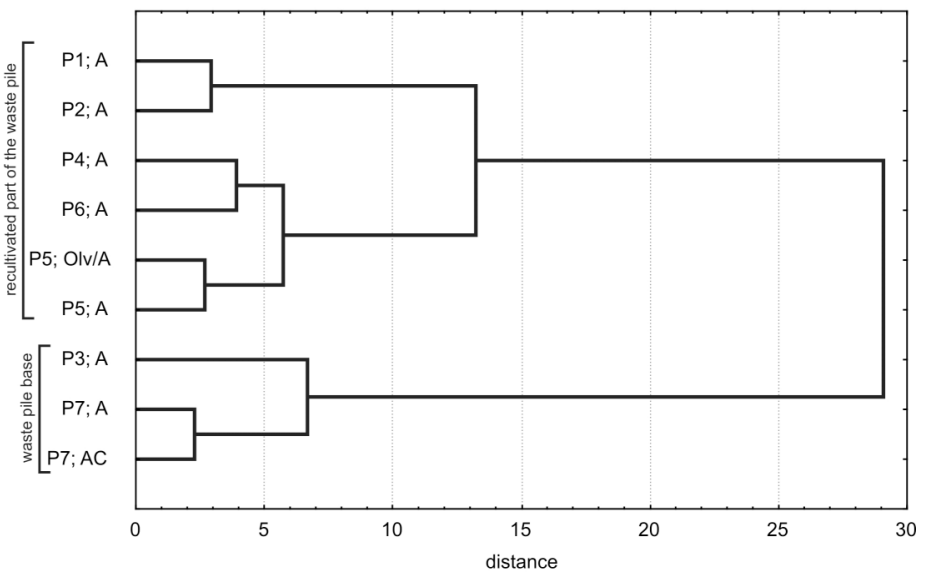

Fig. 2 A. Selected chemical parameters (TOC, T-OM, HA/FA) of the humic A-horizon received from the individual soil profiles; B. Insignificant negative correlation of the total organic matter (T-OM) and the total organic C (TOC) within humic A-horizon in P1-P7; C. Cluster analysis (Ward's method; Euclidean distances) of the basic chemical analyses ( $\mathrm{pH} / \mathrm{H}_{2} \mathrm{O}$ and $\mathrm{pH} / \mathrm{KCl}$ excluded) within the A (or AC) horizon. Profiles situated close to the recultivated top of the waste pile show similar chemistry each other.

Soil air temperature remained above zero in all probes during both monitoring days. Temperature of the soil air was $1.8 \pm 0.54$ (standard deviation) and $5.6 \pm 2.79^{\circ} \mathrm{C}$, relative humidity was $97.3 \pm 1.86$ (standard deviation) and $90.2 \pm 4.07 \%$ in February and March, respectively. Soil air $\mathrm{CO}_{2}$-levels exceeded outdoor air values. Depending on the site, these values range from 510 to 1510 ppmv in February and from 440 to $1380 \mathrm{ppmv}$ in March. Very high values were recorded for sample 8 . Mean values were $722 \pm 227$ (standard deviation) and $686 \pm 214$ ppmv in February and March, respectively. At higher March temperature, the $\mathrm{CO}_{2}$ levels surprisingly did not increase, which is in contradiction to the well known soil $\mathrm{CO}_{2}$-temperature dependence. The soil $\mathrm{CO}_{2}$ levels are in the common range exhibited by natural soils during the same period of the year and indicate advanced stage of humification.

\section{CONCLUSIONS}

1. Intensive humification was the main pedogenetic process in the initial stages of mine soil evolution at the 
Kukla-Václav Nosek waste pile; Translocation of clay minerals is missing even in the soil profiles evolving for about 60 years $(\mathrm{P} 7)$;

2. The youngest soil (P6) situated on the top of the waste pile has the most stable granular aggregates, in average of 3 $\mathrm{mm}$. The stability of aggregates corresponds to the increased representation of the total organic matter $(\mathrm{T}-\mathrm{OM}=2.57)$ in comparison with the topsoil of remaining soil profiles;

3. Humus quality of the present topsoils in the KuklaVáclav Nosek waste pile is substantially influenced by the biological recultivation.

Acknowledgements. This project was supported by the research project MSM 0021622412.

\section{R E F E R E N C E S}

Ammons, J.T., Sencindiver, J.C. 1990, Minesoil mapping at the family level using a proposed classification system. Journal of Soil and Water Conservation, 45: 567-571.

Benfeldt, E.S., Burger, J.A., Daniels, W.L. 2001, Quality of Amended Mine Soils After Sixteen Years. Soil Science Society of America Journal, 65: 1736-1744.

Bradshaw, A.D. 1987, The reclamation of derelict land and the ecology of ecosystems. In Restoration ecology: $A$ synthetic approach to ecological research. (Jordan, W.R., Gilpin, M.E. \& Aber, J.D., Eds.). Cambridge University Press, Cambridge, UK.

Daniels, W.L., Haering, K.C. \& Galbraith, J.M. 2004, Minesoil morphology and properties in Pre-and PostSMCRA Coal mined landscapes in Southwest Virginia. In Publications of the National Meeting of the American Society (Daniels, W.L., Ed.), p. 421-449, ASMR, Montavesta $\mathrm{Rd}$., Lexington.

Deaton, C., Balsam, L. 1991, Visible method for determining hematite and goethite concentration in geological matherials. Journal of Sedimentary Research, 61 (4): 628-632.

Dokoupilová, P., Šráček, O. \& Losos, Z. 2007, Geochemical behaviour and mineralogical transformations during spontaneous combustion of a coal waste pile in Oslavany, Czech Republic. Mineralogical Magazine, 71 (4): 459-476.
Gobat, J.M., Aragio, M. \& Matthey, W. 2004, Fundamentals of soil science and biology. Science Publisher inc., Enfield, New Hampshire, 602 p.

Haering, K.C., Daniels, W.L. \& Galbraith, J.M. 2004, Appalachian Mine Soil Morphology and properties: Effects of the Weathering and Mining Method. Soil Science Society of America Journal, 69: 1315-1325.

IUSS Working Group WRB 2006, World reference base for soil resources 2006. World Soil Resources Reports No. 103. FAO, Rome.

Němeček, J., Smolíková, L. \& Kutílek, M. 1990, Pedology and paleopedology. Academia, Praha, 546 p. (in Czech).

Plchová, J. 2002, Rosice-Oslavany coal basin in dates. Městský výbor, Oslavany, 87 p. (in Czech).

Sencindiver, J.C. 1977, Classification and genesis of minesoils. Ph. D. Diss. West Virginia Univ., Morgantown (Diss. Abstr. 77-22746).

Sencindiver, J.C., Ammons, J.T. 2000, Minesoil Genesis and Classification. In Reclamation of Drastically Disturbed Lands. Agronomy Series, Chapter 12 (Barnishel, R.I., Daniels, W.L. \& Darmody, R.G., Eds.), p. 1-20, American Society for Agronomy. Madison.

Sencindiver, J.C., Ammons, J.T. \& Delp, C.H. 1978, Classification of minesoils - a proposed suborder. In Abstracts of the $11^{\text {th }}$ International Congress of Soil Science, 230 p. Edmonton, Canada.

Thomas, D.W., Jansen, I. 1985, Soil development in coal mine spoils. Journal of Soil and Water Conservation, 40: 439-442.

Thomas, K.A., Sencindiver, J.C., Skousen, J.G. \& Gorman, J.M. 2000, Soil horizon development on mountaintop surface mine in Southern West Virginia. 1-12. Agricultural and Natural Resources Development, West Virginia University.

Thurman, N.C., Sencindiver, J.C. 1986, Properties, classification, and interpretations of minesoils at two sites in West Virginia. Soil Science Society of America Journal, 50: 181-185.

Thurman, N.C., Sencindiver, J.C., Ammons, J.T. \& Adamo, D.C. 1985, Physical properties of minesoils and their effects on root growth. In Proceedings of the Fifth Better Reclamation with Trees Conference, p. 194-208. Southern Illinois University, Carbondale. 